\title{
ODDZIAŁYWANIE MASS MEDIÓW NA KSZTAŁTOWANIE STYLU ŻYCIA DZIECI KLAS 4-6 W BIALSKICH SZKOŁACH PODSTAWOWYCH
}

\section{INFLUENCE OF MASS MEDIA ON SHAPING THE LIFESTYLE OF CHILDREN IN GRADES 4-6 IN BIALA PODLASKA'S PRIMARY SCHOOLS}

\section{Małgorzata Siedlecka $^{1(\mathrm{~A}, \mathrm{~B}, \mathrm{C}, \mathrm{D}, \mathrm{E}, \mathrm{F}, \mathrm{G})}$, Wioletta Żukiewicz-Sobczak ${ }^{1(\mathrm{~A}, \mathrm{~B})}$, Sebastian Sobczuk $^{1(\mathrm{~A}, \mathrm{~B}, \mathrm{~F})}$}

${ }^{1}$ Państwowa Szkoła Wyższa im. Papieża Jana Pawła II w Białej Podlaskiej, Wydział Nauk o Zdrowiu i Nauk Społecznych

Siedlecka, M., Żukiewicz-Sobczak, W., Sobczuk S. (2019). Oddziaływanie mass mediów na kształtowanie stylu życia dzieci klas 4-6 w bialskich szkołach podstawowych. Rozprawy Społeczne, 13(1), 34-42. https://doi.org/10.29316/rs.2019.04

Wkład autorów:

A. Zaplanowanie badań

B. Zebranie danych

C. Dane - analiza i statystyki

D. Interpretacja danych

E. Przygotowanie artykułu

F. Wyszukiwanie i analiza

literatury

G. Zebranie funduszy
Tabele: 8

Ryciny: 5

Literatura: 14

Otrzymano: październik 2017

Zaakceptowano: czerwiec 2018

\begin{abstract}
Streszczenie
Celem głównym niniejszej pracy było poznanie pozytywnych oraz negatywnych aspektów korzystania ze środków masowego przekazu, a cel szczegółowy to zbadanie ich oddziaływania na styl życia dzieci klas 4-6 w bialskich szkołach podstawowych.

Metody i techniki badania: Badanie przeprowadzono w lutym 2017 roku w Społecznej Szkole Podstawowej i w Szkole Podstawowej nr 5 w Białej Podlaskiej. W badaniu wzięło udział 100 uczniów, zastosowaną metodą była metoda sondażu diagnostycznego z wykorzystaniem kart autorskiego projektu ankiet i autorskiego kwestionariusza. Pytania zawarte w kwestionariuszu dotyczyły ilości czasu codziennie poświęcanego przez uczniów na korzystanie z różnych mass mediów oraz ich wpływu na styl życia dzieci. Obliczenia statystyczne wykonano w programie PQStat.

Wyniki: Charakterystykę grupy badanej przeprowadzono na 100 uczniach z podziałem na klasy, płeć, miejsce zamieszkania, ilości czasu poświęconego na korzystanie z mediów.

Wnioski:

- W badanej grupie uczniów można stwierdzić, iż środki masowego przekazu oddziałują na ich styl życia.

- Badane dzieci mają najczęściej kontakt z mediami poprzez telefon komórkowy, Internet, telewizję oraz komputer.

- Największy wpływ zdaniem badanych na kształtowanie zachowań i wychowanie uczniów ma szkoła, znajomi, Internet oraz telewizja.
\end{abstract}

Słowa kluczowe: mass media, styl życia, dzieci, środki masowego przekazu.

\section{Summary}

The main purpose of the present work was to identify positive and negative aspects of using mass media, and the specific objective is to examine their impact on the lifestyle of children in grades 4-6 in primary schools in Biała Podlaska.

Research methods and techniques: The study was conducted in February 2017 at Społeczna Szkoła Podstawowa (Community Primary School) and Szkoła Podstawowa nr 5 (Primary School No.5) in Biała Podlaska. 100 students participated in the study, the applied research method was the method of a diagnostic survey using surveys and questionnaire forms designed by the author. Queries included in the questionnaire concerned the amount of time devoted daily by students to the use of various mass media and their impact on the children's lifestyle. Statistical calculations were made in the PQStat software.

Results: The study group was characterized with the participation of 100 students divided into groups based on the grade they were in, their sex, place of residence, amount of time spent using media.

Conclusions:

- In the examined group of students, it may be concluded that mass media influence their lifestyle.

- The examined children most often have contact with the media via a mobile phone, the Internet, television and a computer.

- According to the respondents, school, friends, the Internet and television have the biggest influence on the shaping of behaviours and upbringing of pupils.

Keywords: mass media, lifestyle, children

Adres korespondencyjny: Małgorzata Siedlecka, Państwowa Szkoła Wyższa im. Papieża Jana Pawła II w Białej Podlaskiej, ul. Sidorska 95/97, 21-500 Biała Podlaska, e-mail: gosia19720610@o2.pl, tel. 83344 9900. ORCID: Wioletta Żukiewicz Sobczak https://orcid.org/0000-0002-0142-5102 Sobczuk 


\section{Wstęp}

Tematem pracy jest oddziaływanie mass mediów na kształtowanie stylu życia dzieci klas 4-6 ze szkół podstawowych. Jest to istotny aspekt dotyczący rozwoju intelektualnego i emocjonalnego dzieci. Celem głównym poniższych rozważań było poznanie pozytywnych i negatywnych aspektów korzystania ze środków masowego przekazu oraz ich oddziaływanie na styl życia badanych dzieci z bialskich szkół podstawowych. Obecnie media są ważnym elementem środowiska wychowawczego dzieci i młodzieży. Dzieci od najmłodszych lat codziennie z olbrzymim zainteresowaniem i zafascynowaniem wchodzą $\mathrm{w}$ świat środków masowego przekazu, który zasadniczo różni się od realnego. Rzeczywistość środków przekazu jest odrealniona, upozorowana, a także ogromnie atrakcyjna i wzbudzająca bardzo duże zainteresowanie odbiorców. Jest to świat zupełnie odmienny, niż ten w którym funkcjonuje dziecko. Nierzeczywisty i wielobarwny świat mass mediów charakteryzuje się ogromną zmiennością obrazów, wzorów zachowań, poglądów oraz opinii. Jest to przestrzeń łatwych sukcesów, odkryć, niezliczonych ilości informacji i zdarzeń, ale również odsłona przemocy, agresji, pornografii oraz tragedii. Właśnie takich dwuznaczności współczesnej rzeczywistości doświadcza dorastające dziecko od najmłodszych lat (Izdebska, 2007, s. 8, 9). Ciekawym staje się poznanie procesu wychowawczego współczesnych dzieci i młodzieży w dobie elektronicznych środków przekazu. Można zadać wiele podstawowych pytań odnoszących się do powyższego tematu, oto niektóre z nich: Jakie miejsce zajmuje dziecko $\mathrm{w}$ świecie mass mediów i jak one oddziałują na jego rozwój?, Jakie korzyści czerpie dziecko ze współczesnych mass mediów?, Jakie zagrożenia one stwarzają?, Jakie zmiany zachodzą w stylu życia dzieci pod wpływem korzystania ze środków telematycznych? (Więczkowska, 2012, s. 10). Współczesny świat uzewnętrznia nie istniejące i nieznane do tej pory problemy społeczne. Większość z nich związana jest z rewolucją technologiczną. Rodzi się nowa generacja uzależnień, która wiąże się z korzystaniem z Internetu i innych mass mediów. Sa one bardzo niebezpieczne, ponieważ człowiek nie odczuwa, kiedy zostaje wplątany w sieć wirtualnej cyberprzestrzeni z której trudno mu się wydostać (Andrzejewska i in., 2008, s. 28). Osobami najbardziej narażonymi na uzależnienia są: dzieci, osoby młode, zagubione, sfrustrowane, potrzebujące dowartościowania, cierpiące na zaburzenia emocjonalne z zaniżoną samooceną, traktujący korzystanie z mass mediów jako ucieczkę od rzeczywistości (Chwaszcz, Pietruszka i Sikorski, 2005, s. 83). Wszystkie wymienione zachowania związane $\mathrm{z}$ użytkowaniem środków masowego przekazu wpływają bezpośrednio, bądź pośrednio na kształtowanie styl życia dzieci. Styl życia współczesnych dzieci i młodzieży uwarunkowany jest m.in. procesem organizacji nauczania, bazy mate- rialnej szkół, poziomem wiedzy około medycznej i kadry pedagogicznej. Jest on ściśle związany ze środowiskiem domowym uczniów i warunkami ekonomicznymi oraz socjalno - bytowymi rodziny. Środki masowego przekazu inaczej mass media, media, komunikatory, są to środki społecznego komunikowania się o szerokim zasięgu. To urządzenia i instytucje za pomocą, których przesyłane są treści do bardzo licznej oraz ogromnie zróżnicowanej publiczności. Wpływają one na tworzenie systemu komunikowania w kulturze masowej. Wyróżnikiem środków masowego przekazu jest ich ogromny (ponadregionalny, ogólnokrajowy, globalny) zasięg. Treści udostępniane przez komunikatory mają charakter publiczny i są masowo odbierane przez ogół społeczeństwa. 0 masowych cechach mass mediów decyduje nie ich wprowadzenie, ale upowszechnienie, które jest możliwe dzięki dobrze rozwiniętej technice i technologii informatycznej. Dla dynamicznego rozwoju środków masowego przekazu istotny wpływ mają rozwiązania ekonomiczne i poziom społeczny edukacji. Planowanym działaniem mediów jest wymieszanie, a następnie ujednolicenie wstępnie jednorodnych elementów zawartych w jednym przekazie. Takie działania mają ułatwić odbiór informacji i przykuć zainteresowanie różnych grup społecznych i przynieść, jak największe zyski. Media masowe w obecnych czasach stały się jednym z najważniejszych elementów władzy społecznej, mobilizacji oraz innowacyjności. Są one głównym narzędziem transmisji i źródłem informacji niezbędnej do funkcjonowania instytucji publicznych. Wpływaja one na tworzenie systemu komunikowania w kulturze masowej (Więczkowska, 2012, s. 10-12). Nowymi mediami definiuje się środki przekazu, które wykorzystują technologię cyfrową. Służą one porozumiewaniu się ludzi, a ich cechą jest ciągłe i szybkie doskonalenie parametrów, miniaturyzacja, standaryzacja, obniżenie kosztów jednostkowych, zmniejszenie kosztów użytkowania oraz interaktywność. Wspólną cechą współczesnych komunikatorów jest ekran, który posiadają, ale również wirtualność, multimedialność, audiowizualność i interaktywność (Hopfinger, 2002, s. 25). Rodzaje współczesnych mass mediów:

- media tradycyjne - takie, w których komunikacja odbywa się tylko w jednym kierunku np. książka, muzyka, film,

- media interaktywne - rodzaj mediów, w których przekaz możliwy jest w obydwie strony np. Internet,

- media gorace i zimne - sa to media, które za pomocą kanałów( radio, telewizja) i przekazywanych informacji pozwalają na swobodną interpretację usłyszanych informacji oraz wiadomości,

- media wolnego kroku oraz media szybkiego kroku - do tych mediów zaliczamy prasę, książki, telewizję oraz radio. Ich główna cechą jest odbiór pewnych wiadomości, w zależności od ich rodzaju - odbiór silny (prasa i książka), bądź 
słaby (telewizja i radio) (pzspg.swiebodzice. szkolnastrona.pl - godz. 10.30, 21 luty 2017).

Styl życia jest to zespół zachowań oraz postaw zdrowotnych, które warunkują zarówno stan zdrowia jednostki, a także populacji. Zachowania zdrowotne są to wszelkiego rodzaju zachowania związane ze zdrowiem jednostki, które stanowią elementy codziennego życia, a także wpływają na stan zdrowia. Zaliczamy do nich działania polegające na praktycznym wykorzystywaniu posiadanej wiedzy w obrębie zdrowia i choroby. Są one indywidualnymi wyborami i decyzjami jednostki, mają wpływ na zdrowie i każdy człowiek ma nad nimi kontrole (Kulik, Latarski, 2002, s. 75-76). Na styl życia wpływ ma wiele czynników np.: środowisko, normy społeczne i kulturowe, w których żyje człowiek i społeczność do której należy lub z którą się identyfikuje. Styl życia człowieka zależy od wartości, przekonań, umiejętności życiowych, a także struktury ekonomicznej, politycznej i organizacyjnej. W przypadku dzieci duży wpływ na styl życia mają ich rodzice i opiekunowie. Zachowanie zdrowotne jest to postępowanie, działanie lub jego zaniechanie, które bezpośrednio, bądź pośrednio wpływa na zdrowie i samopoczucie człowieka. (Jaczewski, Komosieński, 2004, s. 17-20). Nowe media wywierają ogromny wpływ na kształtowanie współczesnych stylów życia zarówno osób dorosłych, jak też młodzieży i dzieci, a także mają bezpośredni wpływ na zmianę norm zachowań społecznych. Styl życia współczesnych dzieci i młodzieży uwarunkowany jest m.in. procesem organizacji nauczania, bazy materialnej szkół, poziomem wiedzy medycznej kadry pedagogicznej. Jest on ściśle związany ze środowiskiem domowym uczniów i warunkami ekonomicznymi, socjalno - bytowymi rodziny.

Do niedostatków w zachowaniach prozdrowotnych u dzieci i młodzieży zaliczamy:

- małą aktywność fizyczną w czasie wolnym, znacząca dysproporcja między czasem przeznaczanym na ćwiczenia fizyczne, a korzystanie ze środków masowego przekazu,

- niewłaściwe odżywianie: nieodpowiednie spożywanie warzyw i owoców, ciemnego pieczywa, mleka, zbyt duże spożywanie węglowodanów, głownie cukrów prostych, tłustych i wysoko przetworzonych przekąsek, brak pierwszych i drugich śniadań oraz podjadanie między posiłkami,

- niedostateczna higiena jamy ustnej,

- używanie alkoholu, papierosów i innych środków psychoaktywnych (Jaczewski i Komosieński, 2004, s. 17-18).

Zdrowy styl życia dotyczy pozytywnych zachowań sprzyjających zdrowiu takich jak:

- odpowiednia aktywność fizyczna,

- racjonalne odżywianie,

- higiena ciała i utrzymanie czystości otoczenia,

- bezpieczeństwo komunikacyjne,

- właściwe relacje między ludźmi,

- nieuleganie nałogom,
- umiejętne radzenie sobie ze stresem,

- czerpanie przyjemności z życia.

Najistotniejszym i pierwotnym elementem kształtującym zachowania zdrowotne jest socjalizacja. Człowiek uspołecznia się i buduje w sobie system wartości, postaw i wzory zachowań. Proces socjalizacji jest ciągły i nie dotyczy wyłącznie zaplanowanych oddziaływań, ale również procesów niezamierzonych. Ludzie uczą się funkcjonować w społeczeństwie przez obserwację i naśladownictwo, wzmacnianie i przekazy symboliczne. Podstawowych czynności życiowych dziecko uczy się w środowisku rodzinnym, tutaj poznaje sposoby aktywności ruchowej, nawyki higieniczne oraz żywieniowe, a także uczy troszczyć się o zdrowie. Rodzice są także źródłem prezentowania dziecku negatywnych nawyków. Nie zachęcają dzieci do aktywności fizycznej, ale pozwalają na wielogodzinne spędzanie czasu przed mass mediami. Bez zastanowienia kupują dzieciom słodycze, napoje gazowane, produkty typu „Fast food”. Kreują złe nawyki pijąc w obecności dzieci alkohol i paląc papierosy lub używając narkotyków. Takie zachowania stymulują i prowokują dzieci do sięgania po substancje uzależniające. Bogactwo proponowanych informacji, kontaktów społecznych, wiadomości, gier oraz wielorakiej aktywności staje się pozytywnym aspektem rozwoju, ale również niesie wiele zagrożeń. Jest to „uwięźnięcie w sieci”, które wyklucza spędzanie czasu wolnego w prozdrowotnej formie, zaburza prawidłowy rozwój dziecka, zniewala szkodliwymi wzorcami stylu życia. Dzieci pozostawione same sobie są nieprzygotowane do procesu dorastania, rozumienia sensu dziejących się zdarzeń, do dokonywania prawidłowych wyborów, nie radzą sobie w grupie rówieśniczej i nie są gotowe na trudne wyzwania, a także przeżywania porażek i radości. Tempo dzisiejszego życia jest wyjątkowo niekorzystne dla prawidłowego i systematycznego rozwoju dzieci i młodzieży, dlatego tak ważna staje się rola wychowawców. Oni powinni projektować i organizować środowisko społeczne i wychowawcze oraz wykorzystywać potencjał posiadanej wiedzy na wywołanie zmian w zachowaniach życia jednostki i zbiorowości. Wszyscy profesjonaliści powinni zjednoczyć swoje siły, aby uczyć całe społeczeństwo, jak właściwie spędzać i zagospodarować czas wolny (Winiarski, 2011, s. 231-233). Współczesne środki przekazu kreują rzeczywistość społeczną. Dzisiejsze społeczeństwo jest zależne od mediów, jak w przeszłości od kościoła, szkoły, rówieśników, czy rodziców. Głównym celem społecznej teorii mass mediów jest mediacja kontaktu z rzeczywistością społeczną. Współczesne środki przekazu są określane jako:

- „okno” na zdarzenia i przeżycia innych, to potęguje ludzkie odczucia oraz postrzeganie świata, przybliża informacje odnośnie wydarzeń w świecie bez udziału innych osób, „zwierciadło" wydarzeń, którego celem jest w miare dobre odbicie, jednak zakładające zniekształcenie obrazu przez dysponentów mediów, 
- „filtr”, który dokonuje selekcji, ale przedstawia wydarzenia, jednocześnie uniemożliwia poznanie innych,

- „drogowskaz” interpretator, który pokazuje sens zdarzeń w innej formie, (Goban-Klas, 2004, s. 114-116).

Pierwsze naukowe badania dotyczące wpływu mass mediów na odbiorców miały już swój początek w latach trzydziestych XX wieku i zaprzeczyły twierdzeniu, że mogą one w nieograniczonym stopniu oddziaływać na ludzkie zachowania i postawy. Zaprzestano uważać, że kształtują one formy zachowań odbiorców, a zaczęto zauważać, że osobowość jest czynnikiem modyfikującym owe oddziaływanie. Stwierdzono, iż indywidualne predyspozycje osobowościowe danego człowieka wpływają na formę przetwarzania informacji $\mathrm{z}$ mass mediów i wtedy zachodzi prawdopodobieństwo odbierania tych samych interpretacji w odmienny sposób. To różnicowanie osobowości wpływa na efekt uczenia się. Kolejne badania przeprowadzono w latach sześćdziesiątych i miały zazwyczaj na celu ustalenie katalogu potrzeb. Zadawano pytania: jakie media mogą zaspokajać i czy faktycznie zaspokajają potrzeby odbiorców? Były one prowadzone do zbudowania typologii użytkowania i korzyści. Która pyta, co odbiorca robi z mediami? Czyli, jakie funkcje pełnią mass media względem odbiorców. Słabość tych koncepcji tkwi w braku adekwatnych do założenia o istnieniu zróżnicowanych potrzeb ram klasyfikacji i operacjonalizacji samych potrzeb. Często są one definiowane tautologicznie: istnienie danej potrzeby wyprowadzane jest z konkretnego zachowania i następnie, to zachowanie jest wyjaśnione za pomocą tej właśnie potrzeby (Kozłowska, 2006, s. 58 - 59).

\section{Materiał i metody badania}

Badanie zostało przeprowadzone w dwóch szkołach podstawowych na terenie miasta Biała Podla- ska, była to Społeczna Szkoła Podstawowa oraz Szkoła Podstawowa nr 5. W badaniu wzięło udział 100 uczniów (w tym 52 chłopców i 48 dziewczyn). Na podstawie analizy miejsca zamieszkania wykazano, iż spośród wszystkich badanych największą grupę stanowili uczniowie $\mathrm{z}$ miasta - 75 osób, natomiast ze wsi - 25 uczniów. Płeć, miejsce zamieszkania i klasa - to cechy, które różnicowały uczniów, biorących udział w badaniu. Charakterystykę badanej grupy przedstawiono $\mathrm{w}$ tabeli 1 .

Tabela 1. Charakterystyka badanej grupy

\begin{tabular}{|c|c|c|c|}
\hline \multicolumn{4}{|c|}{ Płeć } \\
\hline & Dziewczyna & Chłopiec & Ogółem \\
\hline \multicolumn{4}{|l|}{ Klasa } \\
\hline IV & 15 & 17 & 32 \\
\hline V & 17 & 18 & 35 \\
\hline $\mathrm{VI}$ & 16 & 17 & 33 \\
\hline ogółem & 48 & 52 & 100 \\
\hline \multicolumn{3}{|c|}{ Miejsce zamieszkania } & Ogółem \\
\hline Wieś & 14 & 11 & 25 \\
\hline Miasto & 34 & 41 & 75 \\
\hline ogółem & 48 & 52 & 100 \\
\hline
\end{tabular}

Źródło: Opracowanie własne

Respondenci zostali poproszeni o określenie ilości czasu, który poświęcają na korzystanie z mediów. Na telewizję uczniowie najczęściej poświęcają od 1-2 godzin (40\%), do 1 godziny - 34\%, a powyżej 2 godzin - 26\%. Korzystanie z Internetu zajmuje respondentom najczęściej 1-2 godziny (36\%), 32\% uczniów surfuje po Internecie do 1 godziny dziennie, $14 \%$ po $3-4$ godzin dziennie a $18 \%$ więcej niż 4 godziny dziennie. $1 /{ }_{5}$ respondentów posługuje się telefonem w czasie do 1 godziny dziennie, 30\% do 2 godzin, 14\% między 3, a 4 godzinami, powyżej 4 godzin korzysta $16 \%$ uczniów. Ponad połowa ankietowanych (52\%) gra w gry komputerowe do 1 godziny

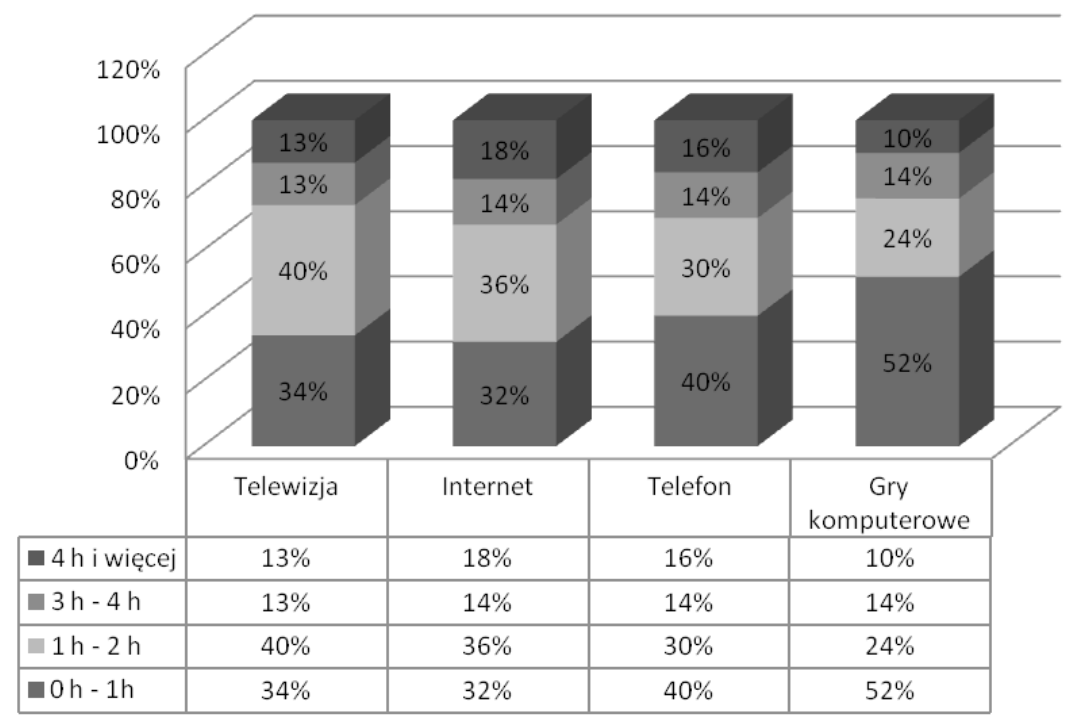

Rycina 1. Czas korzystania z mediów określony w godzinach przez uczniów Źródło: Opracowanie własne 
dziennie, 24\% uczniów do 2 godzin dziennie, 14\% po 3-4 godziny, a 10\% więcej niż 4 godziny (rycina 1.).

Badając zależność między płcią i klasą ankietowanych, a czasem korzystania z telefonu i Internetu stwierdza się brak statystycznie istotnych zależności między badanymi zmiennymi $(p>0,05)$. Badając zależność między płcią i klasą, a czasem korzystania z telewizji i gier komputerowych stwierdza się, że występuje statystycznie istotna różnica między badanymi zmiennymi $(\mathrm{p}<0,05)$, chi2 Pearsona = $0,03 *$ i chi2 Pearsona $=0,01^{*}$ (tabela 2.). Najmniej czasu przed telewizją spędzają dziewczynki w VI klasie ( od 0 h-1 h). Analizując wyniki stwierdza się, że dziewczynki z klasy IV i V również poświęcają w porównaniu z grupą badawczą znacznie mniej czasu, od 1 h-2 h dziennie. Statystycznie najwięcej czasu na korzystanie z telewizji poświęcają chłopcy z klasy V. Porównując płeć pod względem korzystania z gier komputerowych, stwierdza się, że chłopcy niezależnie od wieku znacznie więcej czasu poświęcają na korzystanie z komputera w celu rozrywki. Statystycznie najwięcej czasu na gry komputerowe poświęcają chłopcy z klasy V (tabela 2.).

Wśród mediów, z których uczniowie korzystaja najczęściej wymieniano: Internet i telefon komórkowy - po $26 \%$, telewizję - $23 \%$, komputer - $21 \%$ i prasę - 4\% (rycina 2.).

Badając zależność między płcią i klasą ankietowanych, a rodzajem używanych mediów stwierdza się brak statystycznie istotnych zależności między badanymi zmiennymi ( $p>0,05)$, (tabela 3.).

Tabela 2. Analiza zależności płci i klasy ankietowanych, a czasem korzystania z mediów

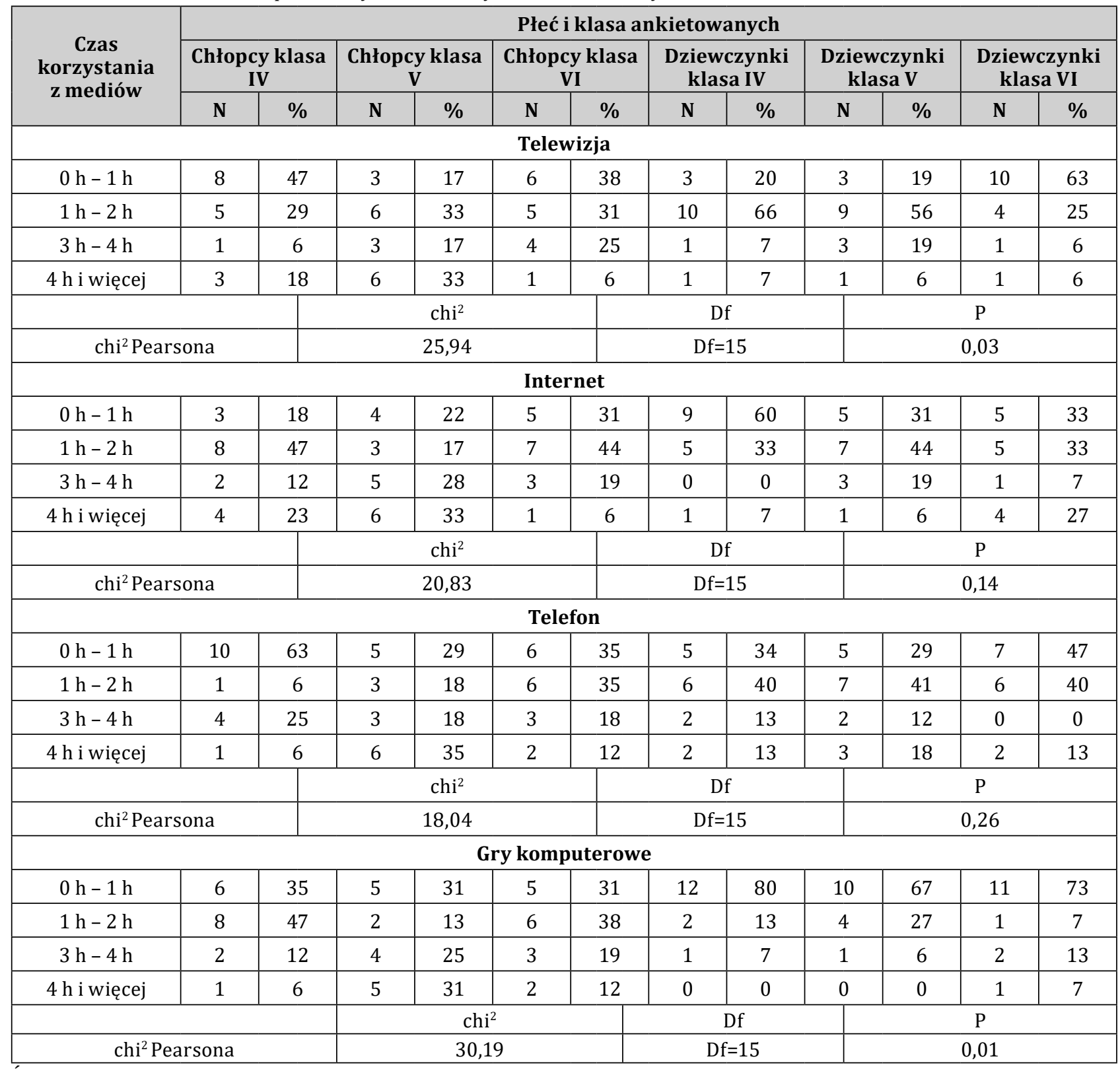




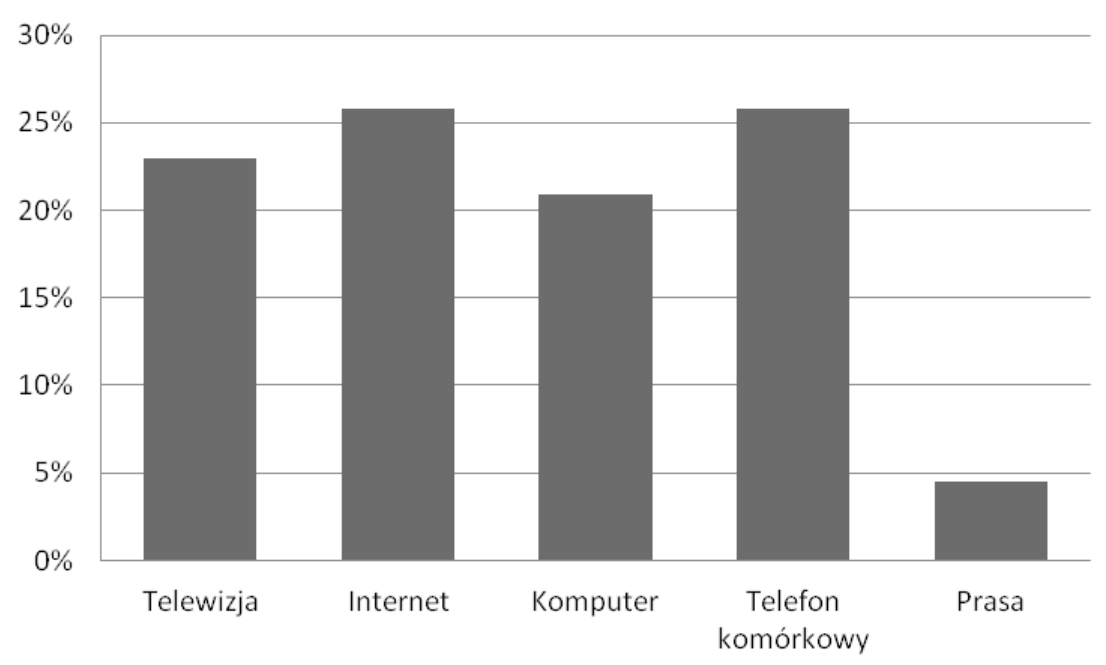

Rycina 2. Media z których korzystają ankietowani

Źródło: Opracowanie własne

Tabela 3. Rodzaj używanych mediów z uwzględnieniem płci i klasy badanych dzieci

\begin{tabular}{|c|c|c|c|c|c|c|c|c|c|c|c|c|}
\hline \multirow{3}{*}{$\begin{array}{c}\text { Rodzaj } \\
\text { używanych } \\
\text { mediów }\end{array}$} & \multicolumn{12}{|c|}{ Płeć i klasa ankietowanych } \\
\hline & \multicolumn{2}{|c|}{$\begin{array}{c}\text { Chłopcy klasa } \\
\text { IV } \\
\end{array}$} & \multicolumn{2}{|c|}{$\begin{array}{c}\text { Chłopcy klasa } \\
\text { V } \\
\end{array}$} & \multicolumn{2}{|c|}{$\begin{array}{c}\text { Chłopcy klasa } \\
\text { VI } \\
\end{array}$} & \multicolumn{2}{|c|}{$\begin{array}{c}\text { Dziewczynki } \\
\text { klasa IV }\end{array}$} & \multicolumn{2}{|c|}{$\begin{array}{c}\text { Dziewczynki } \\
\text { klasa V }\end{array}$} & \multicolumn{2}{|c|}{$\begin{array}{c}\text { Dziewczynki } \\
\text { klasa VI }\end{array}$} \\
\hline & $\mathbf{N}$ & $\%$ & $\mathbf{N}$ & $\%$ & $\mathbf{N}$ & $\%$ & $\mathbf{N}$ & $\%$ & $\mathbf{N}$ & $\%$ & $\mathbf{N}$ & $\%$ \\
\hline Telewizja & 12 & 24 & 14 & 25 & 11 & 23 & 11 & 23 & 9 & 20 & 9 & 22 \\
\hline Internet & 12 & 24 & 16 & 28 & 11 & 23 & 12 & 26 & 11 & 24 & 12 & 29 \\
\hline Komputer & 13 & 27 & 11 & 19 & 12 & 26 & 8 & 17 & 9 & 20 & 7 & 17 \\
\hline $\begin{array}{c}\text { Telefon } \\
\text { komórkowy }\end{array}$ & 10 & 21 & 14 & 25 & 11 & 23 & 13 & 28 & 15 & 32 & 11 & 27 \\
\hline Prasa & 2 & 4 & 2 & 3 & 2 & 5 & 3 & 6 & 2 & 4 & 2 & 5 \\
\hline & & & \multicolumn{4}{|c|}{ chi $^{2}$} & \multicolumn{3}{|c|}{$\mathrm{df}$} & \multicolumn{3}{|c|}{$\mathrm{P}$} \\
\hline \multicolumn{3}{|c|}{ chi $^{2}$ Pearsona } & \multicolumn{3}{|c|}{4,96} & & \multicolumn{2}{|c|}{$\mathrm{Df}=20$} & & \multicolumn{3}{|c|}{0,99} \\
\hline
\end{tabular}

Źródło: Opracowanie własne

Ankietowani najcześciej mają kontakt z mediami w postaci telefonu komórkowego $-1 / 3$ uczniów.
$27 \%$ respondentów wskazało Internet, $26 \%$ telewizję a $17 \%$ komputer (rycina 3.).

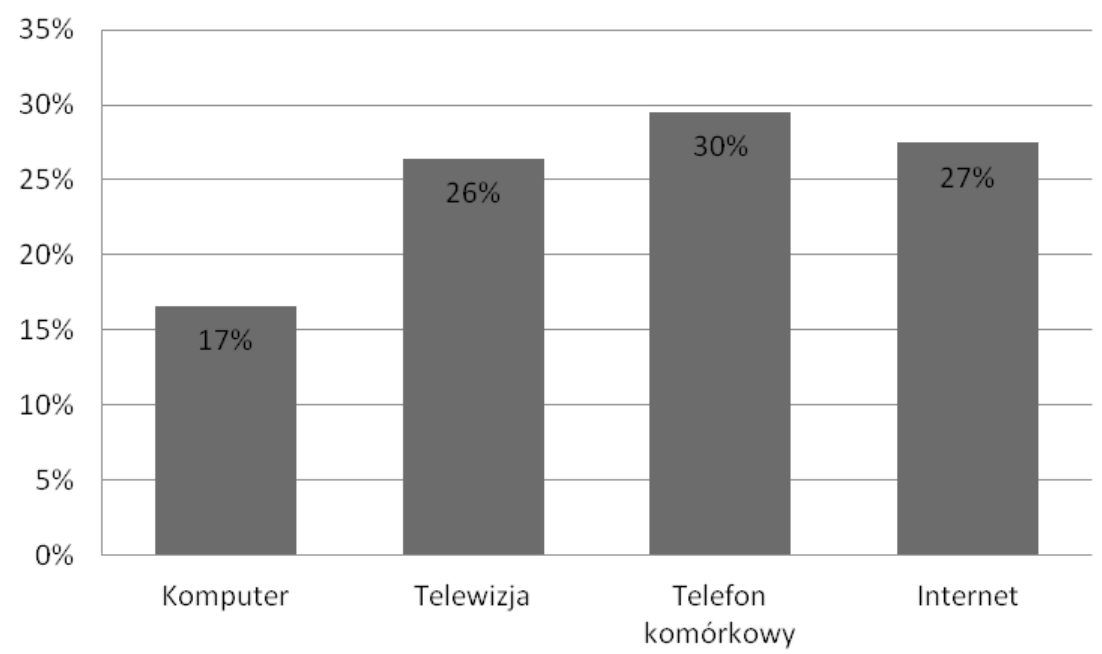

Rycina 3. Media z którymi respondenci mają najczęściej kontakt Źródło: Opracowanie własne 
Badając zależność między płcią i wiekiem ankietowanych, a rodzajem najczęściej używanych mediów stwierdza się brak statystycznie istotnych zależności między badanymi zmiennymi (p > 0,05), (tabela 4.).

$32 \%$ respondentów deklaruje że korzysta z ulubionego środka mass mediów do późna w nocy. $68 \%$ uczniów nie korzysta z mediów do późnych godzin nocnych (tabela 5.).

Badając zależność między płcią i klasą ankietowanych, a korzystaniem $\mathrm{z}$ mediów do późnych godzin nocnych stwierdza się brak statystycznie istotnych zależności między badanymi zmiennymi ( $p>0,05)$, (tabela 6.).

Media dostarczają rozrywki dla $48 \%$ ankietowanych. Środki masowego przekazu są źródłem informacji dla $27 \%$ respondentów, natomiast dla $1 / 4$ uczniów dostarczają kontaktu z rówieśnikami (rycina 4.).

Badając zależność między płcią i klasą ankietowanych, a rodzajem przyjemności dostarczanych przez media stwierdza się brak statystycznie istotnych zależności między badanymi zmiennymi ( $\mathrm{p}>$ 0,05), (tabela 7.).

Tabela 4. Analiza zależności płci i klasy ankietowanych, a najczęściej wykorzystywanymi mediami

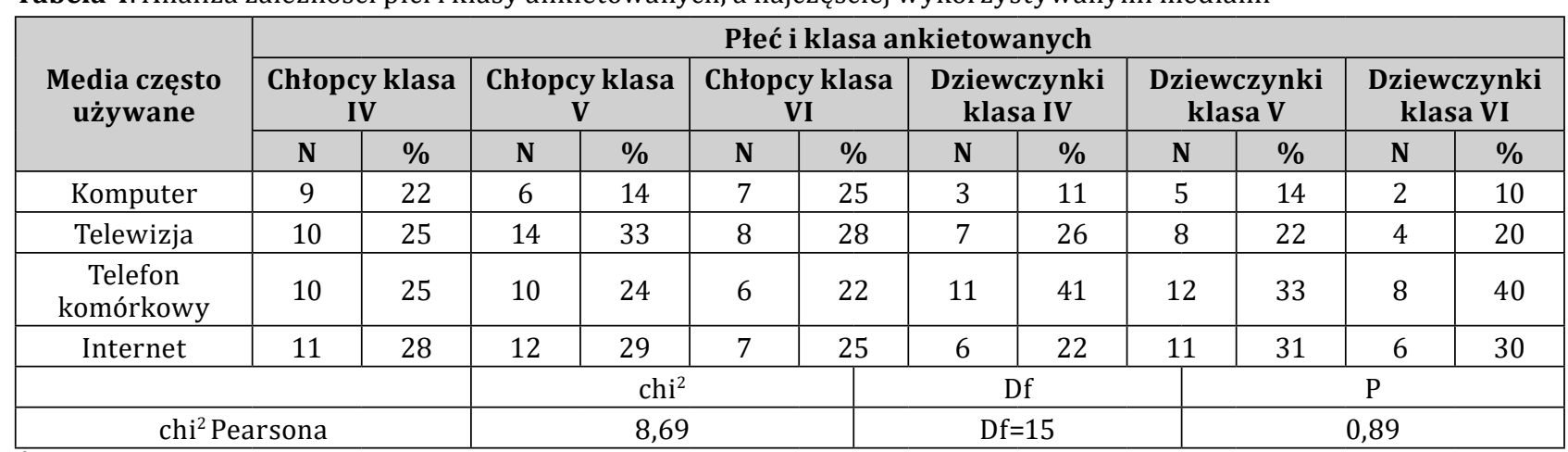

Źródło: Opracowanie własne

Tabela 5. Deklaracja respondentów o korzystaniu z ulubionych mass mediów do późna w nocy

\begin{tabular}{|c|c|c|}
\hline Czy korzystasz z ulubionego środka mass mediów do późna: & $\mathbf{N}$ & $\mathbf{\%}$ \\
\hline Tak & 32 & 32 \\
\hline Nie & 68 & 68 \\
\hline
\end{tabular}

Źródło: Opracowanie własne

Tabela 6. Analiza zależności płci i klasy ankietowanych, a korzystaniem z ulubionego środka mass mediów do późna

\begin{tabular}{|c|c|c|c|c|c|c|c|c|c|c|c|c|}
\hline \multirow{3}{*}{$\begin{array}{l}\text { Korzystanie do } \\
\text { późna z mediów }\end{array}$} & \multicolumn{12}{|c|}{ Płeć i klasa ankietowanych } \\
\hline & \multicolumn{2}{|c|}{$\begin{array}{c}\text { Chłopcy klasa } \\
\text { IV }\end{array}$} & \multicolumn{2}{|c|}{$\begin{array}{c}\text { Chłopcy klasa } \\
\text { V }\end{array}$} & \multicolumn{2}{|c|}{$\begin{array}{c}\text { Chłopcy klasa } \\
\text { VI }\end{array}$} & \multicolumn{2}{|c|}{$\begin{array}{c}\text { Dziewczynki } \\
\text { klasa IV }\end{array}$} & \multicolumn{2}{|c|}{$\begin{array}{l}\text { Dziewczynki } \\
\text { klasa V }\end{array}$} & \multicolumn{2}{|c|}{$\begin{array}{c}\text { Dziewczynki } \\
\text { klasa VI }\end{array}$} \\
\hline & $\mathbf{N}$ & $\%$ & $\mathbf{N}$ & $\%$ & $\mathbf{N}$ & $\%$ & $\mathbf{N}$ & $\%$ & $\mathbf{N}$ & $\%$ & $\mathbf{N}$ & $\%$ \\
\hline Tak & 5 & 29 & 10 & 56 & 5 & 29 & 4 & 27 & 4 & 24 & 4 & 25 \\
\hline Nie & 12 & 71 & 8 & 44 & 12 & 71 & 11 & 73 & 13 & 76 & 12 & 75 \\
\hline & & & \multicolumn{4}{|c|}{ chi $^{2}$} & \multicolumn{2}{|c|}{ Df } & \multicolumn{4}{|c|}{$P$} \\
\hline \multicolumn{3}{|c|}{ chi $^{2}$ Pearsona } & \multicolumn{3}{|c|}{5,81} & & \multicolumn{2}{|c|}{$\mathrm{Df}=5$} & \multicolumn{4}{|c|}{0,32} \\
\hline
\end{tabular}

Źródło: Opracowanie własne

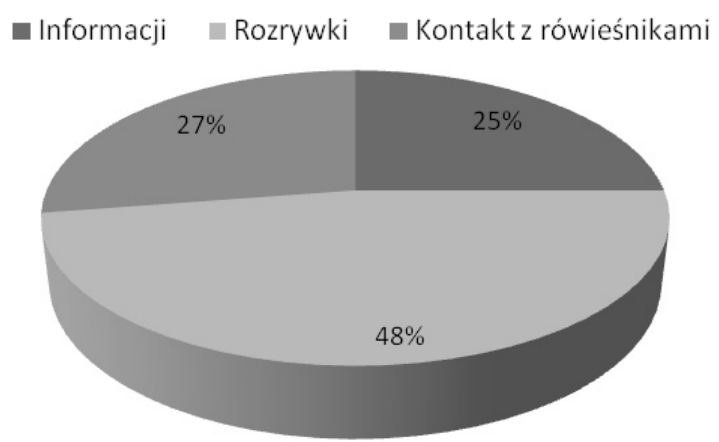

Rycina 4. Co mass media dostarczają badanym dzieciom? Źródło: Opracowanie własne 
Uczniowie wskazują, że największy wpływ na wychowanie i zachowanie ma szkoła (38\%), znajomi (32\%), Internet (16\%) oraz telewizja (14\%) (rycina 5.).

Badając zależność między płcią i klasą ankietowanych, a rodzajem mediów wpływającym na wychowanie i zachowanie stwierdza się brak statystycznie istotnych zależności między badanymi zmiennymi $(\mathrm{p}>0,05)$ (tabela 8.).

\section{Podsumowanie}

Wyniki przeprowadzonych badań oraz analiza literatury przedmiotu skłaniają do sformułowania następujących wniosków:

- Srodki masowego przekazu oddziałują na styl życia badanych uczniów w bialskich szkołach podstawowych. Media głównie dostarczają rozrywki dla ankietowanych dzieci, a także są

Tabela 7. Analiza zależności płci i klasy ankietowanych, a rodzajem mediów wpływających na zachowanie

\begin{tabular}{|c|c|c|c|c|c|c|c|c|c|c|c|c|}
\hline \multirow{3}{*}{$\begin{array}{c}\text { Rodzaj } \\
\text { przyjemności }\end{array}$} & \multicolumn{12}{|c|}{ Płeć i klasa ankietowanych } \\
\hline & \multicolumn{2}{|c|}{$\begin{array}{c}\text { Chłopcy klasa } \\
\text { IV }\end{array}$} & \multicolumn{2}{|c|}{$\begin{array}{c}\text { Chłopcy klasa } \\
\mathbf{V}\end{array}$} & \multicolumn{2}{|c|}{$\begin{array}{c}\text { Chłopcy klasa } \\
\text { VI }\end{array}$} & \multicolumn{2}{|c|}{$\begin{array}{c}\text { Dziewczynki } \\
\text { klasa IV }\end{array}$} & \multicolumn{2}{|c|}{$\begin{array}{c}\text { Dziewczynki } \\
\text { klasa V }\end{array}$} & \multicolumn{2}{|c|}{$\begin{array}{c}\text { Dziewczynki } \\
\text { klasa VI }\end{array}$} \\
\hline & $\mathbf{N}$ & $\%$ & $\mathbf{N}$ & $\%$ & $\mathbf{N}$ & $\%$ & $\mathbf{N}$ & $\%$ & $\mathbf{N}$ & $\%$ & $\mathbf{N}$ & $\%$ \\
\hline Informacja & 8 & 32 & 7 & 23 & 5 & 21 & 7 & 26 & 6 & 19 & 8 & 32 \\
\hline Rozrywka & 11 & 44 & 15 & 48 & 12 & 50 & 14 & 52 & 15 & 47 & 11 & 44 \\
\hline $\begin{array}{c}\text { Kontakt } \\
\text { z rówieśnikami }\end{array}$ & 6 & 24 & 9 & 29 & 7 & 29 & 6 & 22 & 11 & 34 & 6 & 24 \\
\hline & & & \multicolumn{4}{|c|}{ chi $^{2}$} & \multicolumn{2}{|c|}{ Df } & \multicolumn{4}{|c|}{$\mathrm{P}$} \\
\hline \multicolumn{3}{|c|}{ chi $^{2}$ Pearsona } & \multicolumn{3}{|c|}{3,10} & & \multicolumn{2}{|c|}{$\mathrm{Df}=10$} & \multicolumn{4}{|c|}{0,97} \\
\hline
\end{tabular}

Źródło: Opracowanie własne

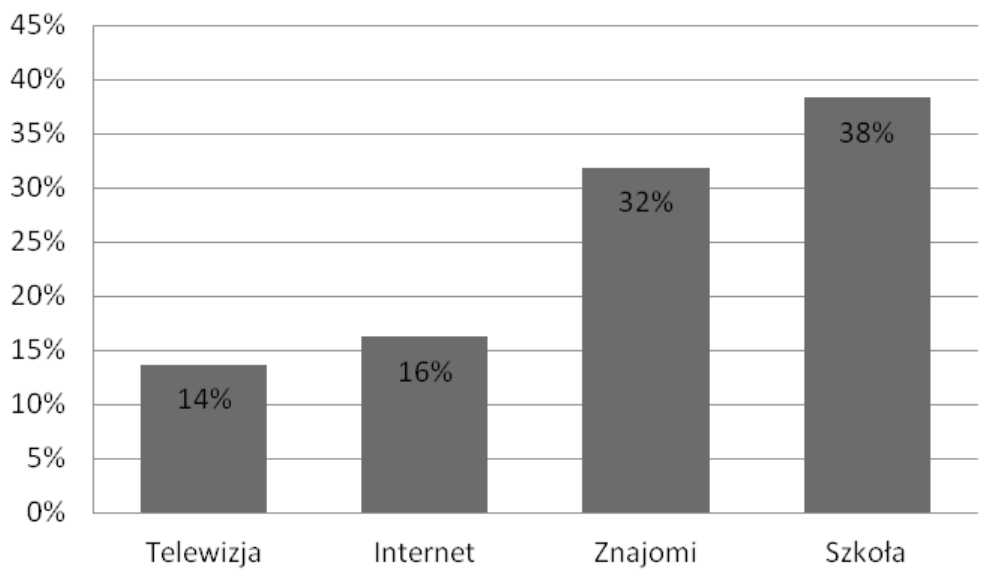

Rycina 5. Analiza mediów, które mają największy wpływ na wychowanie i zachowanie dzieci Źródło: Opracowanie własne

Tabela 8. Analiza zależności płci i klasy ankietowanych, a rodzajem mediów wpływających na zachowanie

\begin{tabular}{|c|c|c|c|c|c|c|c|c|c|c|c|c|}
\hline \multirow{3}{*}{ Rodzaj mediów } & \multicolumn{12}{|c|}{ Płeć i klasa ankietowanych } \\
\hline & \multicolumn{2}{|c|}{$\begin{array}{c}\text { Chłopcy klasa } \\
\text { IV }\end{array}$} & \multicolumn{2}{|c|}{$\begin{array}{c}\text { Chłopcy klasa } \\
\text { V }\end{array}$} & \multicolumn{2}{|c|}{$\begin{array}{c}\text { Chłopcy klasa } \\
\text { VI }\end{array}$} & \multicolumn{2}{|c|}{$\begin{array}{c}\text { Dziewczynki } \\
\text { klasa IV }\end{array}$} & \multicolumn{2}{|c|}{$\begin{array}{c}\text { Dziewczynki } \\
\text { klasa V }\end{array}$} & \multicolumn{2}{|c|}{$\begin{array}{c}\text { Dziewczynki } \\
\text { klasa VI }\end{array}$} \\
\hline & $\mathbf{N}$ & $\%$ & $\mathbf{N}$ & $\%$ & $\mathbf{N}$ & $\%$ & $\mathbf{N}$ & $\%$ & $\mathbf{N}$ & $\%$ & $\mathbf{N}$ & $\%$ \\
\hline Telewizja & 3 & 13 & 9 & 22 & 3 & 12 & 3 & 14 & 3 & 12 & 0 & 0 \\
\hline Internet & 4 & 17 & 9 & 22 & 5 & 20 & 2 & 9 & 4 & 17 & 1 & 5 \\
\hline Znajomi & 7 & 31 & 11 & 27 & 6 & 24 & 7 & 32 & 10 & 42 & 8 & 42 \\
\hline Szkoła & 9 & 39 & 12 & 29 & 11 & 44 & 10 & 45 & 7 & 29 & 10 & 53 \\
\hline & & & \multicolumn{4}{|c|}{$\operatorname{chi}^{2}$} & \multicolumn{2}{|c|}{ Df } & \multicolumn{4}{|c|}{$\mathrm{P}$} \\
\hline \multicolumn{3}{|c|}{ chi $^{2}$ Pearsona } & \multicolumn{3}{|c|}{13,01} & & \multicolumn{2}{|c|}{$\mathrm{Df}=15$} & & \multicolumn{3}{|c|}{0,60} \\
\hline
\end{tabular}

Źródło: Opracowanie własne 
źródłem informacji oraz pozwalają na kontakt z rówieśnikami.

- Uzyskane wyniki badań podkreślają, że badane dzieci najczęściej mają kontakt $\mathrm{z}$ mediami w postaci telefonu komórkowego, Internetu, telewizji oraz komputera.

- Największy wpływ na kształtowanie zachowań i wychowanie badanych uczniów według otrzymanych wyników badań własnych ma szkoła, znajomi, Internet oraz telewizja.

Konkludując wyniki badania można powiedzieć, że są one bardzo pozytywne i budzą optymizm na przyszłość. Wbrew powszechnej opinii, że dzieci i młodzież zatracają swoją tożsamość oraz nie dążą do relacji osobistych $\mathrm{z}$ rówieśnikami przez środki masowego przekazu. Te wyniki wskazuja, że nie jest to prawdą, ponieważ ankietowani uczniowie potrzebują być z grupą rówieśniczą i częściej właśnie wybierają taką formę spędzania czasu wolnego, a nie siedzenie przy środkach telematycznych.
Podsumowując, jednak należy stwierdzić, że telewizja i urządzenia cyfrowe obecne są codziennie, permanentnie w życiu badanych dzieci i ich rodziców, co stanowi realne zagrożenie dla innych wartościowych form aktywności. Rzetelne badania naukowe wskazują na liczne zaburzenia rozwojowe wynikające $\mathrm{z}$ dzieciństwa przebiegającego $\mathrm{w}$ otoczeniu ekranów urządzeń cyfrowych, pilota i myszki. Źródło głównych problemów nie tkwi jednak w samych dzieciach, lecz w świecie, w którym przyszło im żyć. Cywilizacyjnie i kulturowo napędzana adolescencja dzieci ma destrukcyjny wpływ na ich rozwój. Tylko wychowanie polegajace na modelowaniu „ku wartościom" uchroni dzieci przed redukcjonistycznym, fałszywym obrazem świata i siebie, nadmiernym zanurzeniem w nowych technologiach i nieuporzadkowanym konsumpcjonizmem (Jan Paweł II 1995). Współczesne dziecko potrzebuje dobrego wzorca, czyli dojrzałego rodzica i wychowawcy (Jan Paweł II, 1995).

\section{Literatura:}

1. Andrzejewska, A., Bednarek, J., Bożejewicz, W., Chaberska, A. (2008). Dziecko w sieci. Warszawa: Pedagogium.

2. Chwaszcz, J., Pietruszka, M., Sikorski, D. (2005). Media, uzależnienia, fakty i mity. Lublin: Wydawnictwo Goudium i KUL.

3. Goban - Klas, T. (2004). Media i komunikowanie masowe. Warszawa: Wydawnictwo Naukowe PWN.

4. Hopfinger, M. (2002). Nowe media w komunikacji społecznej w XX wieku. Warszawa: Oficyna Naukowa.

5. Izdebska, J. (2007). Dziecko w świecie mediów elektronicznych. Teoria badania, edukacja medialna. Białystok: Wydawnictwo Uniwersyteckie Trans Humana.

6. Izdebska, J. (2009). Rodzina. Dziecko. Telewizja. Kraków: Wydawnictwo Uniwersytetu Jagiellońskiego.

7. Jaczewski, A., Komosieńska, K. (2004). Wybrany zagadnienia z edukacji zdrowotnej, skrypt dla studentów. Płock: Wydawnictwo Uczelnia przyszłości PWSZ w Płocku.

8. Jan Paweł II. (1995). Evangelium vitae W: Encykliki Jana Pawła II, Kraków.

9. Juszczyk S., Polewczyk I. (2006). Dziecko w świeci wiedzy, informacji, komunikacji, Toruń: Wydawnictwo Adam Marszałek.

10. Kozłowska, A. (2006). Oddziaływanie mass mediów. Warszawa: Wydawnictwo Uniwersytetu Jagiellońskiego.

11. Kulik, T., B., Latarski, M. (2002). Zdrowie publiczne podręcznik dla studentów i absolwentów wydziałów pielegniarstwa i nauk o zdrowiu akademii medycznych. Lublin: Wydawnictwo Lekarskie PZWL.

12. Więczkowska, M. (2012). Co wciaga twoje dziecko? Kraków: Wydawnictwo M.

13. Winiarski, R.. (2011). Rekreacja i czas wolny, studia humanistyczne. Warszawa: Oficyna Wydawnicza Łośgraf.

14. www.internetstats.pl. 